\title{
Peranan lingkungan kerja dalam menigkatkan motivasi serta dampaknya pada komitmen organisasi karyawan
}

\author{
R. Zulfikar' ${ }^{1}$, S. Sumiyati\& M. Masharyono \\ Universitas Pendidikan Indonesia \\ ryandi.zulfikar@student.upi.edu
}

\begin{abstract}
The purpose of the research to find out the influence of work environment toward motivation and motivation effect to organizational commitment. The object which became analysis unit in this research are employees of textile industry $X$. This research is using verificative with explanatory survey as a method. Data collection technique used questionnaire with 180 respondents as sample. The result of this research found that the influence of work environment toward the motivation is 69,1\% which was in the strong category. However, motivation affects to employee organizational commitment is 45,3\% which was in the strong category. This research found out that if work environment is conducive, it will increase employee motivation. High motivation will build high organizational commitment. The employees who have high organizational commitment will do the job optimally and more responsible, so that the company could achieve the objectives.
\end{abstract}

Keyword: organizational commitment; work environment; work motivation; textile industry

Abstrak: Tujuan penelitian yaitu untuk mengetahui pengaruh lingkungan kerja terhadap motivasi dan pengaruh motivasi terhadap komitmen organisasi. Objek yang menjadi unit analisis dalam penelitian ini adalah karyawan industri tekstil X. Jenis penelitian yang digunakan adalah verifikatif dengan metode explanatory survey. Teknik pengumpulan data yang digunakan adalah kuesioner dengan jumlah sampel 180 responden. Hasil penelitian ini menemukan bahwa pengaruh lingkungan kerja terhadap motivasi sebesar $69,1 \%$ yang termasuk kedalam kategori kuat dan motivasi berpengaruh terhadap komitmen organisasi karyawan sebesar 45,3\% yang termasuk kedalam kategori kuat. Dalam penelitian ini ditemukan jika kondisi lingkungan kerja kondusif, maka akan meningkatkan motivasi karyawan. Motivasi yang tinggi akan menciptakan tingginya komitmen organisasi. Karyawan yang memiliki komitmen organisasi yang tinggi akan melakuka pekerjaan secara optimal dan lebih bertanggung jawab, sehingga perusahaan bisa mencapai tujuannya.

Kata Kunci: komitmen organisasi; lingkungan kerja; motivasi; industri tekstil.

\section{PENDAHULUAN}

Sumber daya manusia merupakan asset penting dan sangat berpengaruh terhadap efektifitas perusahaan (Elizabeth, 2015: 11), karena sumber daya manusia itu sendiri dapat menunjang organisasi tersebut melalui karya, bakat, kreativitas, dorongan, dan peran nyata mereka (Senen \& Masharyono, 2015: 123). Sumber daya manusia juga merupakan faktor dinamis yang mampu menentukan maju atau mundurnya suatu organisasi (Masharyono, 2012: 2). Karyawan memegang peran utama dalam menjalankan roda kehidupan perusahaan, apabila karyawan memiliki komitmen organisasi tinggi artinya tujuan perusahaan akan tercapai dengan baik (Ebrahim, 2016: 5). Komitmen organisasi dibutuhkan untuk menciptakan dan mempertahankan karyawan yang berkontribusi positif terhadap organisasi demi menunjang tercapainya tujuan dari organisasi (Jain. Ajay K, 2015: 121).

Salah satu indikator kuat dari komitmen organisasi yaitu perilaku turnover, yaitu kecenderungan karyawan untuk meninggalkan pekerjaan (Ghosh \& R, 2014: 6). Terjadinya turnover merupakan suatu hal yang tidak 
dikehendaki oleh perusahaan. Turnover merupakan masalah klasik yang selalu dihadapi para pengusaha dan dianggap penting untuk diperhatikan, karena akan memberikan dampak yang tidak menguntungkan bagi organisasi atau perusahaan (Puspasari, 2014: 5).

Salah satu perusahaan industri di Indonesia yang mempunyai tingkat turnover yang tinggi adalah perusahaan industri tekstil. Industri ini memainkan peranan penting dalam meningkatkan orientasi ekspor khususnya di negara-negara Asia. Persoalan yang mengganggu pencapaian tujuan perusahaan yaitu keluarnya karyawan dari perusahaan atau disebut dengan istilah turnover. Hal ini juga terjadi pada PT pacific Texindo Industy, ditunjukkan pada gambar 1 .

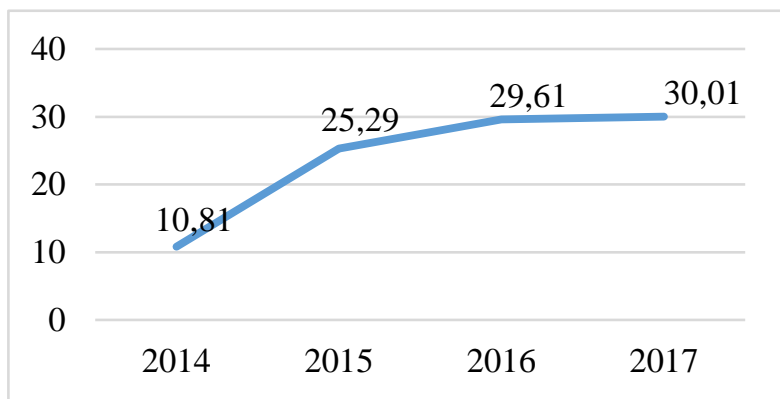

Sumber: Bagian HRD Industri Tekstil X, 2017

Gambar 1. Rata-rata turnover karyawan

Keadaan peningkatan turnover pada Gambar 1 sangat mengkhawatirkan, karena setiap tahunnya turnover karyawan terus meningkat. Keadaan ini sangat merugikan perusahaan apabila dibiarkan, karena semakin meningkatnya turnover maka perusahaan pun akan semakin merugi. Komitmen organisasi yang rendah pada indutri tekstil X selain digambarkan oleh rata-rata turnover karyawan, keadaan ini juga digambarkan oleh persentase ketidakhadiran karyawan bagian produksi.

Tabel 1. Ketidakhadiran karyawan bagian produksi industri tekstil $\mathrm{X}$ tahun 2017

\begin{tabular}{llll}
\hline No & Bulan & $\begin{array}{l}\text { Jumlah } \\
\text { Karyawan }\end{array}$ & $\begin{array}{l}\text { Persentase } \\
\text { Ketidakhadiran }\end{array}$ \\
\hline 1. & 21 Des 2016 - 20 Jan 2017 & 327 & $3,47 \%$ \\
2. & 21 Jan - 20 Feb 2017 & 326 & $3,63 \%$ \\
3. & 21 Feb - 20 Mar 2017 & 330 & $3,67 \%$ \\
4. & 21 Mar - 20 Apr 2017 & 328 & $2,65 \%$ \\
5. & 21 Apr - 20 Mei 2017 & 330 & $2,57 \%$ \\
6. & 21 Mei - 20 Juni 2017 & 329 & $2,52 \%$ \\
7. & 21 Juni - 20 Juli 2017 & 332 & $2,73 \%$ \\
8. & 21 Juli - 20 Agustus 2017 & 330 & $3,59 \%$ \\
9. & 21 Agus - 20 Sept 2017 & 332 & $3,25 \%$ \\
10. & 21 Sept - 20 Okt 2017 & 330 & $4,29 \%$
\end{tabular}

\begin{tabular}{llll}
\hline \multirow{2}{*}{ No } & \multirow{2}{*}{ Bulan } & $\begin{array}{l}\text { Jumlah } \\
\text { Karyawan }\end{array}$ & $\begin{array}{l}\text { Persentase } \\
\text { Ketidakhadiran }\end{array}$ \\
\hline 11. & 21 Okt -20 Nov2017 & 332 & $3,95 \%$ \\
12. & 21 Nov - 20 Des 2017 & 332 & $4,68 \%$ \\
\hline
\end{tabular}

Sumber: Bagian HRD Industri Tekstil X, 2017

Berdasarkan Tabel 1.2 rata-rata presentase ketidakhadiran karyawan PT Pacific Texindo industri mengalamai fluktuasi yang mengkhawatirkan. Persentase ketidakhadiran dari Desember 2016 sampai Desember 2016 didominasi dengan kenaikan hampir setiap bulannya. Kenaikan paling tinggi terjadi pada 21 Septembersampai 20 Oktober 2017 sebanyak $1,04 \%$. Persentase ketidakhadiran yang fluktuatif ini mencerminkan bahwa mereka kurang berkeinginan untuk bekerja dan berusaha ke arah pencapaian tujuan organisasi. Belum optimalnya komitmen terhadap organisasi membahayakan perusahaan itu sendiri, mengingat adanya persaingan dan pasar yang dinamis (McMahon, 2014)

Komitmen organisasi adalah keinginan yang kuat untuk tetap menjadi anggota organisasi, kemauan untuk mengerahkan usaha atas nama organisasi, keyakinan, dan penerimaan, nilai-nilai dan tujuan dari organisasi (Luthans, 2011). Meyer dan Allen menjelaskan terdapat tiga dimensi komitmen organisasi, yaitu affective commitment, continuance commitment, dan normative commitment (Luthans, 2011). Mar'at mengemukakan komitmen seseorang pegawai dipengaruhi beberapa faktor seperti motivasi, kompensasi, pelatihan, fungsi pemimpin, iklim kerjasama, semangat kerja dan konflik yang terjadi di dalam suatu kantor (Putri, 2014: 223).

Adanya motivasi kerja pada karyawan juga akan membuat karyawan tersebut bekerja untuk mencapai tujuan perusahaan sehingga dapat menimbulkan komitmen organisasional karyawan, karena jika karyawan tidak memiliki motivasi biasanya mengalami depresi emosional (Widjajanta, Senen, Masharyono, Lisnawati, \& Anggraeni, 2018). Buraidah mengatakan bahwa motivasi kerja merupakan penyumbang pengaruh paling besar terhadap komitmen organisasional yang berupa tanggungjawab, kemajuan, pekerjaan itu sendiri, pencapaian, pengakuan, administrasi dan kebijakan serta hubungan antar pribadi (Tania \& Sutanto, 2013). Motivasi/kebutuhan 
didefinisikan sebagai suatu kesenjangan atau pertentangan yang dialami antara suatu kenyataan dengan dorongan yang ada dalam diri (Mangkunegara, 2010: 94). Robbin \& Coulter (2012) menjelaskan bahwa motivasi mengacu pada proses dimana upaya seseorang diberi energi, terarah, dan berkelanjutan menuju pencapaian tujuan. Gomez-Mejia \& Balkin (2012) mengemukakan bahwa motivasi berkaitan dengan kekuatan dan arah perilaku dan faktor-faktor yang mempengaruhi orang untuk berperilaku dengan cara tertentu. David McClelland mengemukakan pembentuk motivasi terdiri dari: 1) need for achievement (kebutuhan dalam mencapai kesuksesan), 2) need for power (kebutuhan dalam kekuasaan aau otoritas kerja), 3) need for affiliation (kebutuhan untuk berafiliasi) (Mangkunegara, 2010: 94).

Selain melalui motivasi, faktor lain yang mendominasi komitmen organisasi adalah faktor lingkungan kerja sebagai faktor eksternal karyawan. Shultz dan Schultz mengemukakan kondisi atau lingkungan kerja dapat mempengaruhi karyawan dalam bekerja, baik dari segi lingkungan fisik maupun lingkungan kerja non fisik yang meliputi lingkungan kerja temporer, yang terdiri dari jumlah waktu jam bekerja dan waktu istirahat kerja, serta lingkungan kerja psikologis, yang terdiri dari kebosanan, pekerjaan yang monoton dan keletihan (Mangkunegara, 2010: 105). Menurut Sedamaryanti (2011: 2) bahwa lingkungan kerja adalah keseluruhan alat perkakas, lingkungan di mana seseorang bekerja, metode kerja, serta pengaturan kerja. Lingkungan kerja melibatkan semua aspek yang bertindak dan bereaksi pada tubuh dan pikiran seorang karyawan (Rana \& Hemal, 2016). Lingkungan kerja harus sangat diperhatikan agar tercipta kenyamanan dan komitmen terhadap organisasi, ini akan sangat berpengaruh ke pada motivasi kerja karyawan (Shalahuddin, 2013: 93). Jika lingkungan kerja tercipta dengan baik, maka karyawan akan merasa nyaman dan motivasi kerja karyawan pun akan meningkat.

Berdasarkan latar belakang masalah diatas, maka penulis merumuskan beberapa rumusan penelitian yaitu bagaimana pengaruh lingkungan kerja terhadap motivasi karyawan di industri tekstil $\mathrm{X}$ dan bagaimana pengaruh motivasi terhadap komitmen organisasi karyawan di industri tekstil $\mathrm{X}$. Tujuan dari penelitian ini adalah untuk mengetahui pengaruh lingkungan kerja terhadap motivasi karyawan di industri tekstil $\mathrm{X}$ dan pengaruh motivasi terhadap komitmen organisasi karyawan di industri tekstil X.

\section{METODE PENELITIAN}

Metode yang digunakan dalam penelitian ini adalah metode survey atau explanatory survey. Metode ini bertujuan untuk mengetahui pengaruh antar variabel dengan cara pengujian hipotesis. Unit analisis pada penelitian ini adalah karyawan industri tekstil X pada kurun waktu kurang dari satu tahun yaitu dimulai dari bulan Januari 2018 sampai dengan Mei 2018, sehingga teknik pengumpulan data yang digunakan pada penelitian ini adalah cross-sectional method. Cross sectional method yaitu survei yang dilakukan dengan mengumpulkan data satu persatu dalam satu waktu (Creswell, J., 2012).

Sampel dalam penelitian ini adalah 180 orang karyawan industri tekstil $\mathrm{X}$ dengan penarikan sampel menggunakan metode sampel jenuh, yaitu metode yang mengambil seluruh jumlah populasi. Teknik pengumpulan data yang dilakukan dalam penelitian ini melalui penyebaran kuesioner. Teknik analisis data yang digunakan dalam penelitian ini adalah analisis verifikatif. Analisis verifikatif digunakan untuk melihat pengaruh lingkungan kerja terhadap motivasi dan implikasinya pada komitmen organisasi (Sugiyono, 2017: 147).

Variabel dalam penelitian terdiri dari lingkungan kerja, motivasi dan komitmen organisasi. Penelitian ini menggunakan pengukuran data berskala interval. Skala berusaha mengukur arti suatu objek atau konsep bagi responden. Skala yang digunakan dalam penelitian ini adalah skala Semantic Differential.

\section{HASIL DAN PEMBAHASAN}

Penelitian ini yang terdiri dari variabel bebas yaitu lingkungan kerja $(\mathrm{X})$ sedangkan untuk variabel terikatnya adalah motivasi (Y). Untuk mengetahui 
pengaruh beban kerja terhadap stres kerja dilakukan pengujian regresi linier sederhana. Model persamaan regresi linear sederhana yang akan dibentuk pada penelitian ini sebagai berikut..

$$
\mathbf{Y}=\mathbf{a}+\mathbf{b X}
$$

Sumber: Sugiyono $(2017 ; 192)$

Dimana :

$$
\begin{array}{ll}
\mathrm{Y} & =\text { Motivasi } \\
\mathrm{X} & =\text { Lingkungan kerja } \\
\mathrm{a} & =\text { Bilangan konstanta } \\
\mathrm{b} & =\text { Koefisien regresi }
\end{array}
$$

Berdasarkan hasil pengolahan data dengan bantuan program SPSS 24.0 for windows, diperoleh koefisien regresi linear sederhana sebagai berikut.

Tabel 5. Koefisien korelasi model summary Coefficients $^{\mathrm{a}}$

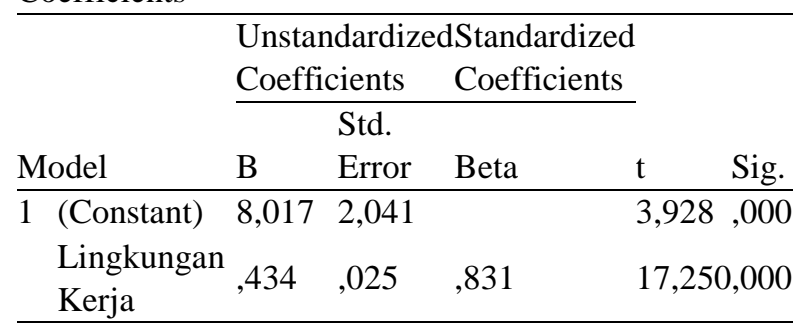

a. Dependent Variable: Motivasi

Sumber: Hasil Pengolahan Data, 2018

Berdasarkan Tabel 5 pada kolom B, tercantum nilai konstanta dan nilai koefisien regresi linear sederhana untuk variabel bebas. Berdasarkan nilainilai itu maka dapat ditentukan model regresi linear sederhana yang dinyatakan dalam bentuk persamaan sebagai berikut:

$$
\begin{gathered}
\mathbf{Y}=\mathbf{a}+\mathbf{b X} \\
\mathrm{Y}=8,017+0,434 \mathrm{X}
\end{gathered}
$$

Berdasarkan persamaan regresi linier sederhana di atas, nilai konstanta sebesar 8,017 menyatakan bahwa jika tidak ada lingkungan kerja, maka besarnya motivasi adalah 8,017 satu satuan nilai. Koefisien regresi pada variabel lingkungan kerja adalah 0,434 yang artinya setiap terjadi penambahan nilai lingkungan kerja akan terjadi peningkatan minat menggunakan sebesar 0,434 satu satuan nilai. Sebaliknya jika terjadi penurunan lingkungan kerja akan menurunkan motivasi sebesar 0,434 satu satuan nilai. Dapat dikatakan bahwa lingkungan kerja akan berpengaruh terhadap tingkat motivasi. Jika lingkungan kerja kurang efektif, maka motivasi akan rendah.
Untuk mengetahui besarnya persentase pengaruh $\mathrm{X}$ terhadap $\mathrm{Y}$, koefisien determinasi dapat diketahui dengan rumus yang dikemukakan Riduwan (2013: 136) yaitu :

Keterangan :

$$
\mathrm{KD}=\mathbf{r}^{2} \times 100 \%
$$

$\mathrm{KD}=$ Koefisien determinasi

$\mathrm{r}=$ Koefisien korelasi

$100 \%=$ Konstanta

Pengaruh lingkungan kerja terhadap motivasi dapat dilihat dari hasil Tabel 6 berikut:

Tabel 6. Koefisien determinasi lingkungan kerja terhadap motivsi kerja

Model Summary

\begin{tabular}{l} 
R $\begin{array}{l}\text { Adjusted } \\
\text { ModelR }\end{array} \quad \begin{array}{l}\text { Std. Error } \\
\text { of the }\end{array}$ \\
$\begin{array}{llll}\text { Durbin- } \\
\text { R Square }\end{array}$ \\
$\begin{array}{ll}\text { Estimate } \\
\text { Watson }\end{array}$ \\
\hline a. Predictors: (Constant), Lingkungan Kerja \\
b. Dependent Variable: Motivasi \\
Sumber: Hasil Pengolahan Data, 2018 \\
$\begin{aligned} \text { KD } & =\mathrm{r}^{2} \times 100 \% \\
& =(0,831)^{2} \times 100 \% \\
& =69,1 \%\end{aligned}$
\end{tabular}

Hasil penghitungan koefisien determinasi di atas untuk lingkungan kerja (X) terhadap motivasi (Y) mengahasilkan persentase sebesar $69,1 \%$. Dengan kata lain motivasi dipengaruhi $69,1 \%$ oleh lingkungan kerja sedangkan 30,9\% dipengaruhi oleh faktor-faktor lainnya diluar lingkungan kerja seperti komitmen organisasi, engagement karyawan, kompensasi, pemeliharaan karyawan dan lain-lain (Mashal \& Nawaz, 2015). Jika dilihat dari koefisien pengaruh sebesar 69,1\% maka berdasarkan tabel Guilford pengaruh lingkungan kerja terhadap motivasi berada pada kategori kuat.

Berbeda dengan hasil penelitian Rezita (2014) yang menyatakan pengaruh lingkungan kerja terhadap motivasi sebesar 16,9\%. Sedangkan hasil penelitian Khoiri (2013) hanya sebesar 21,1\% pengaruh lingkungan kerja terhadap motivasi kerja. Dari penelitian tersebut membuktikan adanya perbedaan hasil yang signifikan antara penelitian terdahulu dengan yang dilakukan peneliti.

Uji statistik t pada dasarnya menunjukkan seberapa jauh pengaruh satu variabel penjelas/independen secara individual dalam 
menerangkan variabel dependen. Untuk mengetahui besarnya persentase pengaruh beban kerja terhadap kinerja. Maka menggunakan program SPSS 24.0 for windows, diperoleh output sebagai berikut:

\section{Tabel 7. Nilai Signifikan Uji t}

Coefficients $^{\mathrm{a}}$

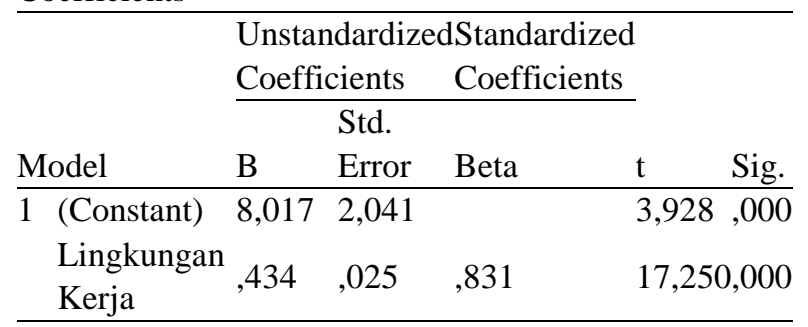

a. Dependent Variable: Motivasi

Sumber: Hasil Pengolahan Data, 2018

Hasil uji $\mathrm{t}$ menunjukan bahwa nilai thitung sebesar 3,928 sedangkan $t_{\text {tabel }}$ dalam penelitian ini adalah 1,65 dengan demikian maka $t_{\text {hitung }}>t_{\text {tabel }}$ atau $3,928>1,65$ adapun nilai signifikansi dari $t_{\text {hitung }}$ adalah 0,000 yang berarti nilai tersebut lebih kecil dari taraf nyata $5 \%$, atau $0,000<0,05$ dengan demikian dapat dibuktikan bahwa $\mathrm{H}_{0}$ ditolak dan $\mathrm{H}_{1}$ diterima yang berarti lingkungan kerja memiliki pengaruh terhadap motivasi. Nilai $t$ positif menunjukan bahwa lingkungan kerja memiliki hubungan yang searah dengan motivasi, artinya apabila nilai lingkungan kerja meningkat maka nilai motivasi akan meningkat, sebaliknya jika nilai lingkungan kerja menurun maka nilai motivasi juga menurun.

Hal tersebut sejalan dengan hasil penelitian yang dilakukan oleh Rezita (2014). Hasil penelitian tersebut menunjukkan bahwa lingkungan kerja berpengaruh positif terhadap motivasi karyawan, artinya jika kondisi lingkungan kerja yang diciptakan semakin baik, maka motivasi karyawan akan semakin tinggi. Hasil penelitian yang dilakukan Prakoso (2014) juga mengemukakan bahwa lingkungan kerja berpengaruh signifikan terhadap motivasi, yang berarti bahwa lingkungan kerja yang baik, dapat memotivasi karyawan dalam bekerja. Sedangkan Horwitz et al mengemukakan bahwa lingkungan kerja yang penuh inspirasi dan dukungan manajemen puncak dapat memotivasi para pekerja (Saeed \& Nasir, 2016).
Uji statistik $\mathrm{F}$ pada dasarnya adalah untuk menguji keberartian regresi dilakukan dengan menggunakan tabel $\mathrm{F}$ atau uji ANOVA dengan membandingkan $F_{\text {hitung }}$ dan $F_{\text {tabel }}$. Berikut hasil pengujian hipotesis menggunakan uji $F$ (keberartian regresi) berdasarkan perhitungan menggunakan bantuan software SPSS 24 for windows pada Tabel berikut ini.

Tabel 7. Nilai Signifikan Uji F

\begin{tabular}{llllll}
\hline ANOVAa & & & & \\
\hline & Sum of & & Mean & \\
Model & Squares & Df & Square & F & Sig. \\
\hline 1 & Regression964,464 & 1 & 964,464 & $28,046,000 \mathrm{~b}$ \\
& Residual & 3644,105 & 177 & 20,588 & \\
& Total & 4590,569179 & & & \\
\hline
\end{tabular}

a. Dependent Variable: Motivasi

b. Predictors: (Constant), Lingkungan Kerja

Sumber: Hasil Pengolahan Data, 2018

Berdasarkan hasil penelitian dengan menggunakan SPSS 22.0 diperoleh data yang menunjukkan bahwa $F_{\text {hitung }}>F_{\text {tabel }}$ yaitu 28,046>3,05 dengan demikian dapat dikatakan bahwa $\mathrm{H}_{0}$ ditolak dan $\mathrm{H}_{1}$ diterima, dengan demikian model dapat digunakan untuk mengambil kesimpulan.

Sedangkan untuk mengetahui pengaruh motivasi terhadap komitmen organisai dilakukan pengujian regresi linier sederhana. Model persamaan regresi linear sederhana yang akan dibentuk pada penelitian ini sebagai berikut.

$$
\mathbf{Z}=\mathbf{a}+\mathbf{b} \mathbf{Y}
$$

Sumber: Sugiyono $(2017 ; 192)$

Dimana :

$$
\begin{array}{ll}
\mathrm{Z} & =\text { Komitmen organisasi } \\
\mathrm{Y} & =\text { Motivasi } \\
\mathrm{a} & =\text { Bilangan konstanta } \\
\mathrm{b} & =\text { Koefisien regresi }
\end{array}
$$

Berdasarkan hasil pengolahan data dengan bantuan program SPSS 24.0 for windows, diperoleh koefisien regresi linear sederhana sebagai berikut.

Tabel 8. Koefisien korelasi model summary

Coefficients $^{\mathrm{a}}$

\begin{tabular}{l} 
UnstandardizedStandardized \\
Coefficients Coefficients \\
\hline Std.
\end{tabular}

$\begin{array}{llllll}\text { Model } & \mathrm{B} & \text { Error } & \text { Beta } & \mathrm{t} & \text { Sig. }\end{array}$ 
1 (Constant) $12,1163,999 \quad 3,030,003$

$\begin{array}{llll}\text { Motivasi } & 1,594,892 \quad 17,250,000\end{array}$

a. Dependent Variable: Komitmen organisasi

Sumber: Hasil Pengolahan Data, 2018

Berdasarkan Tabel 8 pada kolom B, tercantum nilai konstanta dan nilai koefisien regresi linear sederhana untuk variabel bebas. Berdasarkan nilainilai itu maka dapat ditentukan model regresi linear sederhana yang dinyatakan dalam bentuk persamaan sebagai berikut:

$$
\begin{gathered}
\mathbf{Z}=\mathbf{a}+\mathbf{b} \mathbf{Y} \\
Z=12,116+1,594 \mathrm{Y}
\end{gathered}
$$

Berdasarkan persamaan regresi linear sederhana di atas, nilai konstanta sebesar 12,116 menyatakan bahwa jika tidak ada motivasi, maka besarnya komitmen organisasi adalah 12,116 satu satuan nilai. Koefisien regresi pada variabel lingkungan kerja adalah 1,594 yang artinya setiap terjadi penambahan nilai motivasi akan terjadi peningkatan komitmen organisasi sebesar 1,594 satu satuan nilai. Sebaliknya jika terjadi penurunan motivasi akan menurunkan komitmen organisasi sebesar 1,594 satu satuan nilai. Dapat dikatakan bahwa motivasi akan berpengaruh terhadap tingkat komitmen organisasi. Jika motivasi kurang efektif, maka komitmen organisasi akan rendah.

Untuk mengetahui besarnya persentase pengaruh $\mathrm{Y}$ terhadap $\mathrm{Z}$, koefisien determinasi dapat diketahui dengan rumus yang dikemukakan Riduwan (2013: 136) yaitu :

$$
\mathrm{KD}=\mathbf{r}^{2} \times 100 \%
$$

Keterangan :

$$
\mathrm{KD} \quad=\text { Koefisien determinasi }
$$

$\mathrm{r}=$ Koefisien korelasi

$100 \%=$ Konstanta

Pengaruh motivasi terhadap komitmen organisasi dapat dilihat dari hasil Tabel 9 berikut:

\begin{tabular}{|c|c|c|c|c|c|}
\hline \multicolumn{2}{|c|}{ elR } & $\begin{array}{l}\mathrm{R} \\
\text { Square }\end{array}$ & $\begin{array}{l}\text { Adjusted } \\
\text { R Square }\end{array}$ & $\begin{array}{l}\text { Std. Error } \\
\text { of the } \\
\text { Estimate }\end{array}$ & $\begin{array}{l}\text { Durbin- } \\
\text { Watson }\end{array}$ \\
\hline 1 &, $673^{\mathrm{a}}$ & ,453 & ,443 & 4,651 & 1,776 \\
\hline
\end{tabular}

Tabel 4. Koefisien determinasi motivasi terhadap komitmen organisasi

Model Summary ${ }^{\mathrm{b}}$

a. Predictors: (Constant), Motivasi

b. Dependent Variable: Komitmen organisasi

Sumber: Hasil Pengolahan Data, 2018

$\mathrm{KD}=\mathrm{r}^{2} \times 100 \%$

$$
\begin{aligned}
& =(0,673)^{2} \times 100 \% \\
& =45,3
\end{aligned}
$$

Hasil penghitungan koefisien determinasi di atas untuk motivasi (Y) terhadap komitmen organisasi (Z) mengahasilkan persentase sebesar 45,3\%. Dengan kata lain komitmen organisasi dipengaruhi $45,3 \%$ oleh motivasi sedangkan $54,7 \%$ dipengaruhi oleh faktor-faktor lainnya diluar motivasi seperti pengaruh engagement karyawan, lingkungan kerja, pelatihan karyawan, pemeliharaan karyawan, pemberian kompensasi dan lain-lain (Mashal \& Nawaz, 2015). Jika dilihat dari koefisien pengaruh sebesar 45,3\% maka berdasarkan tabel Guilford pengaruh motivasi terhadap komitmen organisasi berada pada kategori cukup kuat.

Berbeda dengan hasil penelitian yang dilakukan Moi (2017) mengenai pengaruh motivasi kerja terhadap komitmen organisasi yang berpengaruh sebesar 32,9\%. Sedangkan hasil penelitian yang dilakukan oleh Wardhani, Susilo, \& Iqbal (2015) sebesar 39,3\%. Kedua penelitian tersebut menunjukan kecilnya pengaruh motivasi kerja terhadap komitmen organisasi.

Uji statistik $t$ pada dasarnya menunjukkan seberapa jauh pengaruh satu variabel penjelas/independen secara individual dalam menerangkan variabel dependen. Untuk mengetahui besarnya persentase pengaruh

\begin{tabular}{|c|c|c|c|c|}
\hline & Unsta & ndardize & dStan & \\
\hline & Coeffi & cients & Coef & \\
\hline & & Std. & & \\
\hline Model & B & Error & Beta & Sig. \\
\hline 1 (Constant) & 12,11 & 3,999 & & $3,030,003$ \\
\hline Motivasi & 1,594 & ,092 & ,831 & $17,250,000$ \\
\hline a. Dependent & Jariable & Komit & nen $c$ & \\
\hline Sumber: Hasi & Pengol & ahan Da & $\mathrm{a}, 20$ & \\
\hline Hasil u & $\mathrm{t} n$ & enunju & an $b$ & nilai $t_{\text {hitung }}$ \\
\hline sebesar 17,2 & , sed & gkar & bel $\mathrm{d}$ & nelitian ini \\
\hline adalah $1,65 c$ & & emik & na & $>t_{\text {tabel }}$ atau \\
\hline $\begin{array}{l}17,250>1, \\
\text { adalah } 0,00\end{array}$ & 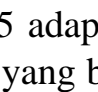 & 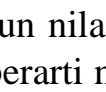 & & \\
\hline
\end{tabular}
motivasi terhadap komitmen organisasi. Maka menggunakan program SPSS 24.0 for windows, diperoleh output sebagai berikut:

\section{Tabel 5. Nilai Signifikan Uji t}

Coefficientsa 
dari taraf nyata $5 \%$, atau $0,000<0,05$ dengan demikian dapat dibuktikan bahwa $\mathrm{H}_{0}$ ditolak dan $\mathrm{H}_{1}$ diterima yang berarti motivasi memiliki pengaruh terhadap komitmen organisasi. Nilai t positif menunjukan bahwa motivasi memiliki hubungan yang searah dengan komitmen organisasi, artinya apabila nilai motivasi meningkat maka nilai komitmen organisasi pun meningkat, sebaliknya jika nilai motivasi menurun maka nilai komitmen organisasi akan menurun pula.

Penelitian Neyshab (2013) juga mendukung bahwa motivasi memiliki dampak positif yang signifikan terhadap komitmen organisasional. Hasil dari penelitian ini menunjukkan bahwa motivasi memiliki dampak positif pada komitmen organisasi karyawan. Didukung oleh pendapat Altindis (2011) bahwa seorang karyawan dapat meningkatkan komitmennya terhadap organisasi jika motivasi yang ada di dalamnya tinggi. Atas dasar pengertian motivasi dan komitmen maka dapat kita ketahui bahwa apabila tenaga kerja memiliki motivasi yang tinggi maka komitmen organisasinya juga tinggi

Uji statistik $F$ pada dasarnya adalah untuk menguji keberartian regresi dilakukan dengan menggunakan tabel $\mathrm{F}$ atau uji ANOVA dengan membandingkan $F_{\text {hitung }}$ dan $F_{\text {tabel }}$. Berikut hasil pengujian hipotesis menggunakan uji $F$ (keberartian regresi) berdasarkan perhitungan menggunakan bantuan software SPSS 24 for windows pada Tabel berikut ini.

Tabel 7. Nilai Signifikan Uji F

\begin{tabular}{|c|c|c|c|c|c|}
\hline \multicolumn{6}{|c|}{$\overline{\text { ANOVA }^{\mathrm{a}}}$} \\
\hline \multicolumn{2}{|c|}{ Model } & $\begin{array}{l}\text { Sum of } \\
\text { Sauares Df }\end{array}$ & $\begin{array}{l}\text { Mean } \\
\text { Saure }\end{array}$ & $\mathrm{E}$ & $\mathrm{Sig}$ \\
\hline \multirow[t]{3}{*}{1} & Regressic & 21004,0441 & 1004,0 & 446 & $8,000^{\mathrm{b}}$ \\
\hline & Residual & 2211,559177 & 12,494 & & \\
\hline & Total & 3215,603179 & & & \\
\hline
\end{tabular}

a. Dependent Variable: Komitmen organisasi

b. Predictors: (Constant), Motivasi

Sumber: Hasil Pengolahan Data, 2018

Berdasarkan hasil penelitian dengan menggunakan SPSS 22.0 diperoleh data yang menunjukkan bahwa $F_{\text {hitung }}>F_{\text {tabel }}$ yaitu 46,408 > 3,05 dengan demikian dapat dikatakan bahwa $\mathrm{H}_{0}$ ditolak dan $\mathrm{H}_{1}$ diterima, dengan demikian model dapat digunakan untuk mengambil kesimpulan.

\section{KESIMPULAN DAN SARAN}

Hasil penelitian menyatakan bahwa lingkungan kerja mempunyai pengaruh terhadap motivasi karyawan dengan kategori sangat kuat. Hal ini menunjukkan bahwa semakin kondusif lingkungan kerja perusahaan, maka semakin tinggi pula motivasi karyawan industri tekstil X. Motivasi berpengaruh terhadap komitmen organisasi karyawan dengan kategori kuat, hal tersebut menunjukkan bahwa semakin tinggi motivasi di perusahaan, maka akan semakin tinggi pula komitmen organisasi karyawan di industri tekstil $\mathrm{X}$.

Berdasarkan hasil penelitian, maka penulis menyarankan beberapa hal yang dapat meningkatkan motivasi organisasi melalui lingkungan kerja. Perusahaan harus berupaya mempererat hubungan dan keakraban antar karyawan, langkah ini dapat ditempuh dengan memperbanyak even gathering dan dipelopori oleh direktur perusahaan. Sedangkan untuk meningkatkan komitmen organisasi karyawan melalui motivasi dapat dilakukan dengan cara perusahaan harus senantiasa dapat mendorong karyawannya untuk berprestasi salah satunya dengan menawarkan pemberian reward bagi karyawan yang mencapai prestasi kerja yang bagus.

\section{DAFTAR PUSTAKA}

Altindis, S. (2011). Job motivation and organizational commitment among the health professionals: A questionnaire survey, 5(21), 8601-8609. https://doi.org/10.5897/AJBM11.1086

Creswell, J., W. (2012). Research design Pendekatan kualitatif, Kuantitatif dan Mixed (Cetakan ke). Yogyakarta: Pustaka Pelajar.

Ebrahim, R. Y. F. (2016). Leadership Styles and Organizationa Commitment. Journal of Management Development, 35(2), 190-216.

Elizabeth, L. (2015). Pengaruh Gaya Kepemimpinan terhadap Komitmen Organisasi pada PT POS Indonesia Semarang. Jurnal Studi Manajemen Dan Organisasi.

Ghosh, S., \& R, S. D. (2014). A Literature Review on Organizational Commitment-A Comprehensive 
Summary, 4(12), 04-14.

Gomez-Mejia, L. R., \& Balkin, D. B. (2012). Management: People, Performance and Change.

Jain. Ajay K. (2015). Volunteerism and Organisational Culture. Cross Cultural Management, 22(1), 116144.

Khoiri, M. M. (2013). Pengaruh Lingkungan Kerja Terhadap Motivasi Kerja Pegawai Perpustakaan di Universitas Negeri Yogyakarta. Universitas Negeri Yogyakarta.

Luthans, F. (2011). Organizational Behavior: An Evidence-Based Approach (12th ed.). New York: McGraw-Hill/Irwin.

Mangkunegara, A. A. A. P. (2010). Manajemen Sumber Daya Manusia Perusahaan. Bandung: PT. Remaja Rosda Karya.

Mashal, A., \& Nawaz, N. (2015). Impact of Organizational Commitment on Employee Turnover: A Case Study of Pakistan International Airlines (PIA). Industrial Engineering Letters, $5(8)$.

Masharyono. (2012). Peningkatan Social Condition, Ability, dan Employe Morale dalam Upaya Pengembangan SDM Indonesia yang Berkualitas. Jurnal.Upi.Edu/1793/View/1555.

McMahon, B. (2014). Organizational Commitment, Relationship Commitment and Their Association with Attachment Style and Locus of Control, 2, 01-16.

Moi, B. (2017). Pengaruh Motivasi Kerja dan Kepusan Kerja Terhadap Komitmen Organisasional Karyawan PT. Sugih Alamanugroho Gunungkidul, D.I. Yogyakarya. Universitas Negeri Yogyakarta.

Neyshabor, A. J. (2013). Asian Research Consortium Work Motivation and Organizational Commitment among Iranian Employees, 1(3), 112.

Prakoso, R. D. (2014). PENGARUH LINGKUNGAN KERJA TERHADAP MOTIVASI KERJA DAN KINERJA KARYAWAN ( Studi Pada Karyawan PT . AXA Financial Indonesia Cabang Malang), 14(2), 1-10.

Puspasari, M. A. W. (2014). Pengaruh Motivasi dan Budaya Organisasi terhadap Komitmen Organisasi dan Kinerja Karyawan.

Putri, F. I. (2014). Hubungan Motivasi Kerja dengan Komitmen Kerja Karyawan di Balai Pendidikan dan Pelatihan Sosial. Jurnal Administrasi Pendidikan, 2(1), 220-231.

Rana, S., \& Hemal, P. (2016). Impact of Work Environment on Employee Job Satisfaction in Sugar Industry: A Study of Tapi District of Gujarat State. Indian Journal of Research, 5(3), 56-61.

Rezita, R. (2014). Pengaruh Lingkungan Kerja
Terhadap Motivasi Kerja Karyawan di Bank Jatim Cabang Utama Surabaya Pengaruh Lingkungan Kerja Terhadap Motivasi Kerja Karyawan di Bank Jatim Cabang Utama Surabaya, 2, 1-15.

Riduwan. (2013). Cara Menggunakan dan Memakai Analisis Jalur (Path Analysis). Bandung: Alfabeta.

Robbin, P. S., \& Coulter, M. (2012). Management. Prentice Hall One Lake Street: Perason Education Inc.

Saeed, H. M. I., \& Nasir, N. (2016). Work Environment on Job Satisfaction with mediating effect of Motivation among School Teachers in Lahore, Pakistan, 564(2015).

Sedamaryanti. (2011). Manajemen Sumber Daya Manusia, Reformasi Birokrasi dan Manajemen Pegawai Negeri Sipil. Bandung: PT Rafika Aditama.

Senen, S. H., \& Masharyono. (2015). Analisis Job Performance Pegawai Honorer Administrasi dengan Kompetensi dan Job Characteristic dalam Mendukung Universitas Pendidikan Indonesia Mencapai Leading dan Outstanding. Fokus Ekonomi, 10(2), 119-137.

Shalahuddin, A. (2013). Pengaruh Kepemimpinan Dan Lingkungan Kerja Terhadap Komitmen Organisasional Dan Kinerja Karyawan Pt. Sumber Djantin. Jurnal Manajemen Teori Dan Terapan, 6(1), 89-104.

Sugiyono. (2017). Metode Penelitian Kuantitatif, Kualitatif dan $R \& D$. Bandung: Alfabeta.

Tania, A., \& Sutanto, E. M. (2013). Pengaruh Motivasi Kerja dan Kepuasan Kerja terhadap Komitmen Organisasional Karyawan PT DAI Knife di Surabaya. AGORA, I(3).

Wardhani, W. K., Susilo, H., \& Iqbal, M. (2015). Pengaruh Motivasi Kerja Karyawan terhadap Komitmen Organisasional dengan Kepuasan Kerja sebagai Variabel Intervening. Jurnal Administrasi Bisnis, https://doi.org/10.1145/3132847.3132886

Widjajanta, B., Senen, S. H., Masharyono, Lisnawati, \& Anggraeni, C. P. (2018). The impaact of Social Media Usage and Self-Esteem on Conspicuous Consumption: Intagram User of Hijabers Community Bandung Member. International Journal of EBusines and EGoverment Studies, 10(2), 1-13. 